\title{
A Rational Regulatory Strategy for Governing Financial Innovation
}

\section{Iris H-Y Chiu*}

\begin{abstract}
Modern financial regulation has predominantly been economically-driven, ${ }^{1}$ progressing from addressing market failures to making markets more competitive and work better. ${ }^{2}$ The UK Financial Conduct Authority is expressly mandated to pursue regulatory objectives that maintain market integrity and protect consumers (addressing market failures) and to promote competition (making markets work better). ${ }^{3}$ Both the FCA and its sister regulator, the Prudential Regulation Authority (for banks) have recently adopted innovative regulatory initiatives to promote technologically-driven innovation, aimed at making markets work better. These initiatives are also a response to the recent explosion of technologically-led financial innovation outside of the regulatory perimeter.
\end{abstract}

In promoting financial innovation, we argue that the regulators have insufficiently focused on the need to govern financial innovation more generally. Although this concern may seem premature, the regulatory innovations are increasingly extending the perimeter for regulatory oversight of financial innovations. As the regulatory innovations have the potential to develop into more mature regulatory frameworks for governing financial innovation, we argue that regulators should manage the risks of their current approach and develop a regulatory strategy framework for balancing regulatory objectives and developing regulatory policy. We propose a framework anchored in rationality, consistency and accountability in governing financial innovation.

Wordcount excluding abstract: 11, 799

\section{Introduction}

Regulation is often seen as antithetical to pro-market objectives, ${ }^{4}$ but the UK Financial Conduct Authority (FCA) has an express mandate to promote competition in financial markets. The FCA's recent endeavours to promote competition has led it to launch Project Innovate ${ }^{5}$ to support technological revolutions in finance ('fintech', ${ }^{6}$ financial regulatory compliance solutions, called 'regtech' and 'techfin'7, which refers to non-finance companies in other sectors that foray into

\footnotetext{
*Professor of Corporate Law and Financial Regulation, UCL. I thank Professor Maria Lee for commenting on an earlier draft, and an anonymous reviewer for very helpful comments in finalising the piece. All errors and omissions are mine.

${ }^{1}$ Summed up in chapter 3, Armour et al, Principles of Financial Regulation (Oxford: OUP 2015). The rationales for financial regulation have progressed from being driven by market efficiency to a broader form of economic public interest, such as in collective financial stability, especially after the global financial crisis 2007-9. See also Mads Andenas and Iris H-Y Chiu, The Foundations and Future of Financial Regulation (Oxford: Routledge 2014). ${ }^{2}$ Gillian Hadfield, 'Producing Law for Innovation' in Kauffman Foundation, Rules for Growth (Missouri 2011) at chapter 2, also note Law in the Flat World (2010) at works.bepress.com/ghadfield.

${ }^{3}$ Sections 1B to 1E, Financial Services and Markets Act 2000 amended by the Financial Services Act 2012.

${ }^{4}$ This point will be discussed in greater detail in Section A. For eg see Giuseppe Nicoletti and Stefano Scarpetta, 'Regulation, Productivity and Growth: OECD Evidence' (World Bank Research Paper 2003); Alain de Serres, Shuji Kobayakawa, Torsten Sløk and Laura Vartia, 'Regulation of Financial Systems and Economic Growth' (OECD Working Paper 2006) at http://ssrn.com/abstract=965693.

${ }^{5}$ See https://www.fca.org.uk/firms/innovate-innovation-hub.

${ }^{6}$ Price Waterhouse Coopers, Blurred Lines: How Fintech is Shaping the Financial Services Industry (March 2016); Douglas Arner, Jànos Barberi and Ross P Buckley, 'The Evolution of Fintech: A New Post-Crisis Paradigm?' (2015) at http://ssrn.com/abstract=2676553.

7 Dirk Zetzsche, Douglas Arner, Ross P Buckley and Janos N Barberis, 'From Fintech to Techfin: The Regulatory Challenges of Data-Driven Finance' (2017) at https://papers.ssrn.com/sol3/papers.cfm?abstract_id=2959925.
} 
financial services as part of the economies of scale achieved in their business models, usually relating to data collection and analytics). ${ }^{8}$ The explosion of 'fintech', 'regtech' and 'techfin' in the recent decade is a marked trend as unconventional or non-traditional products, services and markets have arisen to meet the lacunae left by banks damaged during the global financial crisis 2007-9. ' 'Project Innovate' can be seen as a necessary step for regulators as the boundaries of regulatory policy are being challenged by these new industry developments. ${ }^{10}$ However, regulators also see the potential in these innovations in contributing to more competitive financial markets. Thus, a novel regulatory mechanism known as the 'Regulatory Sandbox ${ }^{11}$ which is part of Project Innovate, is introduced to attract innovative firms (a) to engage in pre-regulatory processes with a view towards helping them launch in market, while (b) also bringing them within the scope of governance and oversight. A similarly dedicated mechanism for financial innovation relating to investment advice has also been established under the FCA's Advice Unit. ${ }^{12}$ The FCA, with its sister regulator for major banks in the UK, the Prudential Regulation Authority (PRA) has also launched the 'New Bank Start-up Unit'13 to promote challenger banks and shake up the landscape for banking services in the UK. The key tenets of the regulatory innovations are: bringing firms into a test environment, suspension of certain regulatory obligations for firms during testing, maintaining close engagement and supervision during testing with a view to considering if the firms and their products or services can be brought to market; and graduation from test environment.

These regulatory innovations currently focus on promoting innovation as regulators attempt to induce firms to emerge from the shadows and engage with regulatory processes at earlier stages. As enrolling into the Regulatory Sandbox or Mobilisation regime is voluntary, much of financial innovation could remain outside the regulatory perimeter, and it may be a while before the new regimes are able to capture a substantial scope of financial innovation. However, as the Sandbox and Mobilisation regimes carve out an 'interim' area of permissible activities, they implicitly offer innovative firms and entities an alternative to the default mode of punitive regulatory enforcement against non-compliant activities. The scope of regulated financial services activities is highly comprehensive under the UK Financial Services and Markets Act 2000,14 so the apparently voluntary nature of the Sandbox and Mobilisation regimes creates incentives for firms to distinguish

\footnotetext{
${ }^{8}$ Douglas Arner, Jànos Barberis and Ross P Buckley, 'FinTech, RegTech and the Reconceptualisation of Financial Regulation' (2017) Northwestern Journal of International Law and Business forthcoming at http://ssrn.com/abstract=2847806; FCA, Call for Input: Supporting the Development and Adoption of RegTech (Nov 2015) and Feedback Statement: Call for Input: Supporting the Development and Adoption of RegTech (July 2016).

${ }^{9}$ See an overview in Iris H-Y Chiu, 'Fintech and Disruptive Business Models in Financial Products, Intermediation and Markets - Policy Implications for Financial Regulators (2016) 21 Journal of Technology Law and Policy 168.

${ }^{10}$ Yeung provides an overview of regulatory response in the face of disruption that threatens to make regulatory policy obsolete or inappropriate- regulators could resist and enforce, or become overwhelmed or indeed choose to grapple with industry changes and adapt intelligently, see Karen Yeung, 'Governance by Blockchain: The Coming Battle for Supremacy Between the Code of Law Vs Code as Law?', speech at the Symposium on Blockchain and the New Financial Order, University College London, 19 June 2017.

${ }^{11}$ FCA, Regulatory Sandbox (Nov 2015).

12 In light of the established market gaps for consumer investment advice, the FCA would look specifically into how financial technology innovation can fill the gap. See FCA, Financial Advice Markets Review (April 2017).

${ }^{13}$ http://www.bankofengland.co.uk/pra/nbsu/Pages/default.aspx.

${ }^{1414}$ S19 and Schedule 2, see also case law that has taken an approach of interpreting the scope of the regulatory perimeter as capturing all functionally equivalent activities as those prescribed in Schedule 2, for eg FSA v Anderson [2010] EWHC 599 (Ch)). Further, see the hugely contested characterisation of land-banking schemes as illegal collective investments which was finally settled in the regulator's favour after several years of litigation, see Asset Land Investment PIc v The Financial Conduct Authority [2016] UKSC 17.
} 
themselves from regulatory arbitrageurs, if not to evade possible antagonistic enforcement. We observe growth in the popularity of these regimes in their second year and the increasing extension of the regulatory perimeter for financial innovation (see Section A). Industry enthusiasm for the Regulatory Sandbox and Mobilisation Initiative shows that there is significant potential for these regulatory innovations to cover a meaningful scope of industry activity, although this remains work in progress. We see the Sandbox and Mobilisation regimes as a first step towards extending the regulatory perimeter over financial innovation, and argue that the regulators are well-positioned to develop these regimes further into comprehensive ones for governing financial innovation, and not merely promoting them for the purposes of enhancing competitive markets.

At the moment, the regulatory innovations are positioned in a welcoming manner to reach out to innovative firms. However, we are concerned that regulators risk becoming too sympathetic towards firms in their desire to promote innovation, and this disposition can be reinforced by intense engagement with firms during the period in the Sandbox or Mobilisation. On the one hand, extensive intelligence can be obtained through such engagement to shape regulatory policy in areas of emerging importance, on the other hand there is a danger of enrolling firms at such an early stage with a potential to rewrite rules. We perceive two key issues of concern. One is that the predominance of the 'servicing' element in the regulators' approach is not balanced by an observed regulatory strategy for governing financial innovation. Second, the intensity in the relational paradigm between regulator and firms may impact upon regulatory objectivity and rationality in designing regulatory policy. Policy and rule-making in governing financial innovation can be captured by the industry.

In governing financial innovation, regulators need to make choices in the complex interrelationships between competition, innovation and other regulatory objectives such as consumer protection and financial stability. This is because the alignment between the objectives served by promoting competition or innovation, and other protective regulatory goals cannot be assumed. ${ }^{15}$ Balance and trade-offs among regulatory objectives and priorities is a matter of regulatory strategy, and we posit this is where governing financial innovation is situated. Greater intensity in the relational paradigm between regulator and firm brings with it risks in terms of how regulatory strategy is ultimately influenced.

The Regulatory Sandbox is being copied in other leading financial jurisdictions. ${ }^{16}$ However, we should not be too quick to think that this regulatory approach has become a 'gold standard'. The quick 'copying' and adaptation by other regulators can merely be due to the fear of being left behind.

Section A explores the FCA's Regulatory Sandbox and the PRA-FCA's Mobilisation initiative for challenger banks. We critically tease out the regulatory risks in this enhanced relational paradigm between firms and regulator that may affect their potential to credibly govern financial innovation. Section B suggests that in governing financial innovation, the FCA's and PRA's regulatory innovations should be grounded in a 'regulatory strategy' framework. Regulatory strategy refers to the balancing exercise needed for the regulators' multiple objectives that are pro-market as well as protective in nature. Further, regulators must recognise that promoting innovation is only a proxy for and is not identical to pursuing competition, and must review assumptions of such alignment. We argue that regulatory strategy can be conducted in a more rational and consistent manner and this provides a

\footnotetext{
${ }^{15}$ Highlighted by the Financial Stability Board, see FSB, Financial Stability Implications from Fintech (27 June 2016) at http://www.fsb.org/2017/06/financial-stability-implications-from-fintech/.

${ }^{16}$ Has been adopted in Hong Kong, Singapore, Australia, Canada and Japan.
} 
framework for optimal regulatory policy and decision-making that mitigates the risks of relational influences. Finally we argue that such a model should be supported by adequate elements of oversight and accountability. Section $\mathrm{C}$ concludes.

\section{A. UK Financial Regulators' Role in Promoting Technology-led Financial Innovation}

The FCA launched the Innovation Hub after extensive consultation in 2014. This is in response to the growing trend in fintech innovation that has arisen to fill market gaps and exploit new efficiencies after the global financial crisis 2007-9 which hit many traditional financial institutions. The Innovation Hub provides a process for regulatory engagement with innovators so as to shed light on the continued relevance of existing regulation to industry practices. ${ }^{17}$ The Innovation Hub comprises of several aspects such as advice and support for innovators, focused themes for innovation such as fintech and regtech, event days for engagement between the FCA and interested constituents, and the Regulatory Sandbox, which is a regulatory mechanism for innovation testing and bringing to market. ${ }^{18}$ An extension of the Sandbox can be found in the FCA's proposal to engage with innovation that deals specifically with plugging market gaps in investment advice. ${ }^{19}$

The PRA's sister outfit is focused on challenger banks in the UK. The New Bank Start up Unit ${ }^{20}$ is a joint initiative by the PRA and FCA and provides a platform for early stage advice and engagement with entrepreneurs that plan to start a new bank. Prospective new banks would then have to go through pre-application discussions to ensure that they have a viable business plan, that they understand the regulatory requirements for being authorised as a bank, and are able to put in process the requirements for regulatory compliance. A special regulatory regime of mobilisation may apply to them as they roll out their operations.

The Regulatory Sandbox and Mobilisation for challenger banks are novel regulatory approaches. They allow regulators to proactively seek new firms or pre-regulatees, moving away from the previous position of being passive and reactive..$^{21}$ Early regulatory engagement with financial innovation may mitigate the dangers of financial innovation being funnelled into shadow finance or areas of regulatory arbitrage. Such a pro-active approach has the potential to capture an increasing scope of financial innovation, as innovators are encouraged to emerge from the shadows and engage with regulators. This approach also emphasises the relational paradigm between firm and regulator ${ }^{22}$ and signals a new dimension of regulatory responsiveness ${ }^{23}$ in co-opting firm and industry opinions to feed into regulatory policies and decisions. As there is an element of 'coaching' involved in assisting firms to become fully operational and compliant, the regulator risks being captured by the innovative and challenger industries.

\footnotetext{
${ }^{17}$ See interview with Martin Wheatley (CEO of FCA 2013-2015), at http://play.buto.tv/DWCTY.

18 https://www.fca.org.uk/firms/innovate-innovation-hub.

${ }^{19}$ FCA, Financial Advice Markets Review (April 2017).

${ }^{20} \mathrm{http}: / /$ www.bankofengland.co.uk/pra/nbsu/Pages/default.aspx.

${ }^{21}$ Nathan Cortez, 'Regulating Disruptive Innovation' (2014) 29 Berkeley Technology Law Journal 175.

22 Described as a 'performative turn' in regulation, loannis Lianos, 'Law, Fintech, and the Performative Turn in Regulation', paper delivered at the Blockchain Technology and a New Financial Order conference, Centre for Law, Economy and Society, 19 June 2017, arguing that the regulator now makes regulatory policy and decisions within a new 'society' of innovators, the financial industry, socially embedding such policies and decisions, perhaps distinguishing from merely being economically driven.

23 'Responsiveness' in regulation first developed in relation to enforcement and securing proportionate enforcement that reinforces meaningful compliance, see lan Ayres and John Braithwaite, Responsive Regulation (Oxford: OUP 1992). This was subsequently developed responsiveness in the supervisory process see Robert Baldwin and Julia Black, 'Really Responsive Regulation' (2008) 71 Modern Law Review 59.
} 
A key tenet in the new regulatory initiatives is regulatory suspension in the test environment. Regulation is suspended in whole or in part, as part of bringing the financial innovation or new bank to market. Such regulatory suspension is temporary and would be clearly delimited in terms of its expiry. However, in order to be eligible for such regulatory suspension, firms undergo an extensive selection process. Thereafter, the regulatory suspension is closely supervised. The regulators set out not to overburden new firms or innovations, while mitigating any potential social harm this may cause. Firms are subject to closer than normal scrutiny, as a tradeoff for these time-delimited regulatory suspensions.

The industry has responded overwhelmingly to the regulators' initiatives. In terms of the Regulatory Sandbox, the FCA has since mid-2015 issued two open calls for applicants. Applicants have to submit a testing plan that details the financial innovation to be tested in the market, the testing parameters such as timelines and key milestones of the testing process, measures for success of testing, customer safeguards, an assessment of the risks of the innovation in question and an exit strategy from testing. ${ }^{24}$ The FCA vets the applications extensively and selects those that the FCA considers to meet the criteria of: offering a genuine innovation and not merely a derivative product; likelihood of generating consumer benefit; having a need to be tested within a sandbox as the nature of the innovation may be unregulated or subject to uncertain regulatory perimeter; and the firm's readiness for testing. ${ }^{25}$ In its first cohort, the FCA received 69 applications and selected 24 applicants for the Sandbox. In the second cohort the FCA received 71 applications and selected 31 firms. ${ }^{26}$ The Advice mechanism is relatively new and discussion is therefore focused on the Sandbox as a template approach.

Regulatory suspension applies to successful applicants in the following manner. Successful Sandbox participants are issued with no-action letters with regard to the scope of activities agreed between them and the FCA. ${ }^{27}$ This is usually a suspension of most regulatory compliance requirements except for customer safeguards. Successful applicants may test financial innovation upon a real consumer base, or in a virtual sandbox. In the former situation, the FCA requires applicants to duly inform customers of the situation and of their safeguards, and does not exempt firms from potentially facing consumer redress or enforcement actions. The FCA would likely also set conditions and provide guidance for each firm in the Sandbox. This live testing environment would only last 3-6 months as individually agreed between the FCA and each successful applicant. The firms are required to keep detailed records and regularly report to the FCA. The matters for reporting would deal largely with achievement of key milestones, consumer outcomes, the conditions imposed by the FCA upon the firm, and other requirements that may be individually agreed. At the end of the testing period, the FCA would make regulatory decisions with regard to each firm based on the extensive intelligence and intensive supervision maintained throughout the testing period.

The Sandbox approach shows that the FCA implicitly accepts that there may be a trade-off between regulation that serves certain objectives, and promoting innovation for sometimes young firms that are not quite able to meet the full suite of regulatory requirements. Customer safeguards are regarded as not to be compromised, but the waiver for each firm is not publicised. We surmise that they may include organisational and prudential requirements, which are usually costly to set up.

\footnotetext{
${ }^{24}$ FCA, Default Standards for Sandbox Testing Parameters at https://www.fca.org.uk/publication/policy/default-standards-for-sandbox-testing-parameters.pdf.

25 https://www.fca.org.uk/firms/innovate-innovation-hub/regulatory-sandbox.

${ }^{26}$ https://www.fca.org.uk/news/press-releases/financial-conduct-authority-unveils-successful-sandbox-firmssecond-anniversary.

${ }^{27}$ FCA, Regulatory Sandbox (Nov 2015).
} 
Regulatory suspension comes with limitations in terms of market reach, thus minimising the risks of adverse impact on public interest as a result of regulatory suspension.

In terms of the PRA's New Bank Start-up Unit, the focus of the Unit is less on innovation but on challenger firms, as potential new banks do not have to offer something novel from established banking business. The key quality is their challenger potential and this arguably relates more directly to the regulatory objective of promoting competition. Nevertheless, Atom Bank which has become fully authorised after a year's mobilisation offers novel and app-based interfaces for its customers, although the range of its products do not depart significantly from established banks.

Firms that intend to enter into the banking business are encouraged to engage with the PRA at an early stage, and the PRA provides early stage advice as well as a more formal channel of preapplication discussions and exploration of issues. When ready, applicants submit formal applications which the PRA will consider against the criteria of: viability of business plan; adequate financial resources; sources of funding; the identities of owner/s and controllers; the firm's corporate governance; the firm's risk management; the firm's customer journey; the firm's outsourcing; the firm's information technology structures; the firm's policies and procedures; the firm's plans for recovery and resolution, as appropriate; and the needs for the firm's business continuity. ${ }^{28}$

The PRA's vetting process includes interviews with individuals that would likely undertake the following roles in the firm: the Senior independent director; Chair of Risk and/or Audit Committee; Chief Executive Officer; Head of Branch (for branches of non EEA-firms); Risk Director/Chief Risk Officer; Finance Director/Chief Finance Officer. The decision-making process would likely take 6 months after which the PRA would inform of the outcome. Successful applicants would then be informed of the scope of authorisation received and whether they would be put through the mobilisation route. Where a new bank is put through the mobilisation route, this means that the PRA has authorised the bank even though it has not fully met the requirements for authorisation. It is expected that the time spent in mobilisation would allow the bank to emerge fully able to meet regulatory requirements.

Mobilisation ${ }^{29}$ allows the PRA to suspend the regulatory requirements in relation to information technology infrastructure and other organisational infrastructure, staff recruitment and engagement with third party suppliers. Banks in mobilisation should nevertheless be able to meet the regulatory requirements relating to a fully-developed and viable business plan, financial resources and corporate governance and a near-complete plan for customer safeguards. It would only need draft plans for IT and organisational infrastructure, business continuity, recovery and resolution, risk management and other policies and procedures- areas where the relevant regulatory requirements are suspended. The bank in mobilisation must also have in place a credible project plan as to how the bank intends to complete its build-up in order to emerge fully operational and compliant at the end of mobilisation.

The mobilisation period would be agreed between the PRA and the new bank, usually at a maximum of 12 months. The new bank's business activities would be restricted during mobilisation, such as not to take deposits above $£ 50,000$. Mobilisation would also be a period of intense supervision by the PRA. Regular reporting by the bank and feedback from the PRA would be expected in order to assist the bank to exit mobilisation. However there may be cases where a bank is unable to become

\footnotetext{
${ }^{28}$ http://www.bankofengland.co.uk/pra/nbsu/Pages/submittingassessing.aspx.

${ }^{29}$ http://www.bankofengland.co.uk/pra/nbsu/Pages/mobilisation.aspx.
} 
fully operational or compliant in 12 months in which case the PRA would likely cancel the authorisation at the end of mobilisation.

The PRA in implementing Mobilisation for challenger banks adopts a trade-off between certain regulatory objectives and promoting bank competition. The compromises are made in relation to the softer requirements of prudential regulation such as governance and risk management and resolution planning, which may be regarded as less important for banks that do not yet have significant scale. Hard prudential requirements such as capital resources and liquidity are however regarded as non-derogable. Further, by indicating that Mobilisation cannot be extended beyond 12 months, the PRA seems to maintain a strong position in terms of ensuring that only financially stable and viable banks come to market. Nevertheless, softer aspects of prudential regulation may be crucial as poor risk management culture and corporate governance have a significant impact upon a bank's risk profile. ${ }^{30}$ The PRA's extensive interviews of individuals may however compensate for the non-insistence of formal compliance.

The regulatory suspension employed in both the Sandbox and Mobilisation shows that regulators implicitly accept that trade-offs in regulatory objectives have to be made in their novel role of promoting innovation. We acknowledge that regulators have not carried this out lightly, as they seek to mitigate the potential market distortive effects that entail from such application of double standards. Firms are restricted in the scope of business they can engage in during testing or mobilisation; the regulatory suspension is delimited by a reasonably short time period (3-6 months for firms in the Sandbox and up to 12 months for banks in Mobilisation); restrictions and conditions are imposed upon business, and firms are subject to an intense supervision environment. The intensity of reporting and supervision for firms in the Sandbox and Mobilisation route arguably exceed what fully authorised firms would experience (under the PRA's and FCA's risk-based supervision approaches that categories supervisory needs according to firm risk). ${ }^{31}$

The FCA's feedback to consultees in 2014 prior to the launch of the Innovation Hub reflected an overwhelming industry perception of the law as being uncertain and potentially burdensome. ${ }^{32}$ The industry fedback that the scope of regulation was uncertain in terms of capturing new financial products and innovations, and that existing regulation, based on certain assumptions in business model and processes, may be ill-fitting for new financial products and services. It is uncertain to what extent the regimes for regulatory suspension in the Sandbox and Mobilisation reflect chiefly industry views, as there is a lack of articulation in terms of the basis upon which the specific regulatory suspensions were determined, and how the balancing exercise is conducted. There is public interest is ensuring that regulatory discretion at such a high level of strategy is exercised in a consistent and well-reasoned manner, as the public have an interest in ensuring the optimal governance of financial innovation.

We argue that the governance of financial innovation should be based on a framework for regulatory strategy, implemented by the Sandbox and Mobilisation initiative. A high-level framework

\footnotetext{
${ }^{30}$ Basel Committee, Guidelines: Corporate Governance Principles for Banks (July 2015) at http://www.bis.org/bcbs/publ/d328.pdf; G30, Banking Conduct and Culture: A Call for Sustained and Comprehensive Reform (July 2015), at http://group30.org/publications/detail/166.

${ }^{31}$ FCA, Journey to the FCA (Oct 2012), at http://www.fsa.gov.uk/static/pubs/other/journey-to-the-fcastandard.pdf; PRA, Our Approach to Banking Supervision (Oct , 2012), at http://www.fsa.gov.uk/static/pubs/other/pra-approach-banking.pdf.

32 FCA, Project Innovate: Call for input Feedback Statement (Oct 2014) at https://www.fca.org.uk/publication/feedback/fs-14-2.pdf.
} 
like this is needed in order to prevent regulatory trade-off decisions from becoming captured by firm-centric bargaining or becoming inconsistent.

The FCA and PRA do not report publicly on the outcomes of the Sandbox and Mobilisation. The first cohort of Sandbox firms have completed their Sandbox time by April 2017. Although their identities are published, the FCA has not published information as to whether the Sandbox firms have graduated to full authorisation, and whether there are lessons learnt for the development of regulatory strategy or policy. The PRA does not publish information on which new bank if any has entered Mobilisation or the outcome of Mobilisation. It is understandable that the specific arrangements between regulators and firms for the purposes of the Sandbox or Mobilisation are confidential. However, public disclosure can be made in terms of the regulators' strategic learning without infringing confidentiality or jeopardising firms' commercially sensitive information.

The implementation of the Sandbox and Mobilisation route should become a means of governing financial innovation and not merely to function as service platforms for the industry. In the next Section, we argue that the Sandbox and Mobilisation route should be based on a framework for regulatory strategy that engages with complex balancing and trade-off decisions. We propose a model that is anchored in rationality, supported by mechanisms of accountability.

\section{B. A Framework for Regulatory Strategy to Govern Financial Innovation}

In promoting technologically-led financial innovation, we cannot assume that there would be no tensions within the suite of regulatory objectives that the FCA and PRA look after. Hence, the regulators' role should not merely be to promote innovation, as firms already do that in their own interest. Instead, regulators should ensure that such promotion falls within a framework for governing financial innovation more broadly. Further, the FCA's regulatory objective is to promote competition, and the regulators' promotion of innovation is a proxy for promoting competition. The alignment between the two should not be readily assumed. Regulators' roles in relation to financial innovation and challenger firms, should ultimately be one of governance and not merely promotion.

Governing financial innovation involves grasping the complex interrelationships between regulation, competition and innovation. First, we set out the context of complex interrelationships between regulation, innovation and competition. Regulation can be seen as antithetical to competition, and/or to innovation, but regulators also play a salient role in shaping and calibrating the landscape for competition and/or innovation. We also argue that regulators' assumption that promoting innovation is identical to promoting competition must be tested and reviewed. Regulators need to develop a strategic framework for choices to be made within these complex interrelationships, and we propose the development of a rational model to be implemented in the Sandbox and Mobilisation initiative towards that end.

\section{Regulation and Competitive Markets}

In an insufficiently competitive market, efficiency losses may result as incumbent firms may be complacent and sub-optimally productive, ${ }^{33}$ and consumers have less choice, resulting in welfare losses. ${ }^{34}$ Serres et $\mathrm{al}^{35}$ find that competitive financial markets are important for the growth of the

\footnotetext{
${ }^{33}$ Francesco Daveri, Rémy Lecat and Maria Laura Parisi, 'Service Deregulation, Competition and the Performance of French and Italian Firms' (2011) at http://ssrn.com/abstract=1950551.

${ }^{34}$ Eg Arie Melnik and Oz Shy, 'Exclusion, Competition, and Regulation in the Retail Loan Market' (2014) at http://ssrn.com/abstract=2374975 on how competitive financial markets promote financial inclusion.

${ }^{35}$ Alain de Serres, Shuji Kobayakawa, Torsten Sløk and Laura Vartia, 'Regulation of Financial Systems and Economic Growth’ (OECD Working Paper 2006) at http://ssrn.com/abstract=965693.
} 
financial services sector, whose size seems to be correlated strongly with economic growth in a country.

Regulation can be perceived as antithetical to competitive markets. Conventional regulatory requirements such as business licensing, business restrictions or control can be seen as entailing anti-competitive effects ${ }^{36}$ as they raise barriers of entry to new firms. To an extent, the perception of regulation being a hindrance to the liberalisation of competitive markets led to extensive deregulation from the 1990s in many global financial jurisdictions ${ }^{37}$ Although in the EU and UK there was less of a marked dismantling of regulation, and financial regulation was modernised and harmonised to promote the Single Market, ${ }^{38}$ pro-market rhetoric was very strong. Enabling facets of regulation (such as the EU passport for financial establishments and provision of cross-border services) preceded protective aspects. ${ }^{39}$ The UK Financial Services Authority (then-regulator and predecessor to the PRA and FCA) also adopted very light-touch approaches ${ }^{40}$ to regulation and supervision, leaving supervisory risks lightly or not highlighted, so that regulated firms would not be excessively burdened by regulation.

The sidelining of regulation has however culminated in the excesses of risk-taking that led to the global financial crisis 2007-9. ${ }^{41}$ Although extensive deregulation has been reversed ${ }^{42}$ since the crisis, there is a need to calibrate different types of regulatory measures for different purposes in order to enable, control or correct different phenomena. Regulation can attack anti-competitiveness in order to maintain market competition. Further, certain types of regulation such as prudential regulation, conduct of business regulation and investor/consumer protection are necessary for public interest objectives that also support a healthy and competitive market. Prudential regulation acts as a check

\footnotetext{
${ }^{36}$ Francesco Daveri, Rémy Lecat and Maria Laura Parisi, 'Service Deregulation, Competition and the Performance of French and Italian Firms' (2011) at http://ssrn.com/abstract=1950551 on the service sector generally in a number of countries under survey; Wulf A Kaal, 'What Drives Dodd-Frank Act Compliance Cost for Private Funds?' (2016) Journal of Alternative Investments at http://ssrn.com/abstract=2629386 on how the introduction of the Dodd-Frank Act 2012 in the US created barriers to entry for smaller new mutual funds.

${ }^{37}$ Simon Deakin, 'The Rise of Finance: What Is It, What Is Driving It, What Might Stop It?' (2008) 30

Comparative Labour Law and Policy Journal 67; on the US, see David G Tarr, 'The Political, Regulatory and Market Failures That Caused the US Financial Crisis' (World Bank Research Paper 2016) however qualifying that it was not de-regulation in terms of the lack of regulation, but rather loosening standards through 'perverse' regulation, a term used in the article, as a form of 'de-governance' that supported financial markets liberalisation.

${ }^{38}$ Mads Andenas and Iris H-Y Chiu, The Foundations and Future of Financial Regulation (Oxford: Routledge 2014) at chapters 2 and 3.

${ }^{39}$ For example the Investment Services Directive 1992 emphasised the EU passport for investment firms and only provided a skeletal set of principles for protecting investors. This relative imbalance was only slowly addressed. We can compare the first Markets in Financial Instruments Directive 2004 that replaced the 1992 Directive with the intense suite of investor-protection reforms in the 2014 Directive that replaced the 2004 one.

${ }^{40}$ FSA, 'The Turner Review: A Regulatory Response to the Global Banking Crisis' (March 2009) http://www.fsa.gov.uk/pubs/other/turner_review.pdf.

${ }^{41}$ Arthur E Wilmarth Jnr, 'The Dark Side of Universal Banking: Financial Conglomerates and the Origins of the Subprime Financial Crisis' (2009) 41 Connecticut Law Review 963; Timothy A Canova, 'Financial Market Failure as a Crisis in the Rule of Law: From Market Fundamentalism to a New Keynesian Regulatory Model' (2009) 3 Harvard Law and Policy Review 369.

${ }^{42}$ Rise of macroprudential regulation, systemic-risk based regulation and greater intensity in prudential and conduct of business regulation overall, see overview in Mads Andenas and Iris $\mathrm{H}-\mathrm{Y} \mathrm{Chiu}$, The Foundations and Future of Financial Regulation (Oxford: Routledge 2014); lain MacNeil and Justin O'Brien (eds), The Future of Financial Regulation (Oxford: Hart 2010); Eilis V Ferran et al, The Regulatory Aftermath of the Global Financial Crisis (Cambridge: CUP 2012).
} 
on financial risk-taking and sustains confidence of financial services users in the firms that they deal with. Conduct of business regulation also sustains consumer confidence as it is aimed at ensuring fair and non-abusive behaviour. Investor and consumer protection standards including disclosure regulation are aimed at overcoming market failures such as information asymmetry or the inequality in bargaining power. These regulatory frameworks underlie and support financial markets, ${ }^{43}$ which may otherwise become a 'jungle' and market for lemons. ${ }^{44}$ Indeed Serres at a ${ }^{45}$ find that business restrictive regulations may be hindrances to competitive financial markets, but prudential and conduct of business regulation do not produce significant hindering impact.

Further, EU financial regulation is market-building in nature and promotes a level playing field for cross-border movement of financial services. ${ }^{46}$ Lianos $^{47}$ situates the positive role of regulation in promoting competition within the paradigm of ordoliberalism, ${ }^{48}$ which is the political-economy philosophy underlying the EU as an economic polity. In this way, regulation is not antithetical to competitive markets and could be a handmaiden to achieving economic outcomes.

However there are instances where promoting market competition could conflict with another regulatory objective and trade-off decisions must be made. For example, as Serres et al discussed, promoting growth in the financial services markets by promoting competition in turn promotes overall economic growth. But growth in financial services may mean the incurring of more household debt such as residential mortgages and unsecured personal loans. High levels of residential mortgage debt could fuel a housing price bubble, while high levels of personal debt may post significant consumer risks and may be unsustainable for the economy. There is scope for regulatory policy to consider restrictions or cooling of activities or marketing ${ }^{49}$ in order to mitigate financial stability or consumer detriment risks. In another example, promoting investment into collectively managed funds (such as occupational pensions) may promote growth in the financial services sector, but high levels of fund management raise challenges for maintaining investment profitability. Asset managers are increasingly chasing returns in unconventional assets that may be illiquid and this raises issues for investor protection in terms of liquidity risks as well as systemic risks that can ensue when investors collectively withdraw from funds. ${ }^{50}$ Staikouras \& Wood also argue

\footnotetext{
${ }^{43}$ See for eg discussion in Michel Klein and Colin Mayer, ' Mobile Banking and Financial Inclusion: The Regulatory Lessons' (2011) at http://ssrn.com/abstract=1846305.

${ }^{44}$ Where 'good' firms are driven from the market and only 'bad' firms remain as consumers are unable to differentiate between the two, therefore disincentivising 'good' behaviour.

${ }^{45}$ Alain de Serres, Shuji Kobayakawa, Torsten Sløk and Laura Vartia, 'Regulation of Financial Systems and Economic Growth' (OECD Working Paper 2006) at http://ssrn.com/abstract=965693.

${ }^{46}$ Maria Manuel Leitão Marques and Leonor Bettencourt Nunes, 'Deepening the Freedom of Services through Pro-competitive Regulation' (2013) at http://ssrn.com/abstract=2350701; Eilis V Ferran, Building an EU Securities Market (Cambridge: CUP 2004) on how legal integration is market-building in nature for the EU; Iris $\mathrm{H}-\mathrm{Y}$ Chiu, Regulatory Convergence in EU Securities Regulation (The Hague: Kluwer 2008) on how regulatory convergence relates to textual laws and law in action.

${ }^{47}$ Ioannis Lianos, 'The Interaction Between Competition Law and State Action: Looking Inside the Black Box (of the State)' (2012) at http://ssrn.com/abstract=2334208.

${ }^{48}$ C Joerges, "The Law in the Process of Constitutionalising Europe" EUI Working Paper 2002/4, (Florence: European University Institute 2002).

${ }^{49}$ Bank of England, The Financial Policy Committee's powers over Housing Tools: A Policy Statement (July 2015) at http://www.bankofengland.co.uk/financialstability/Documents/fpc/policystatement010715.pdf. ${ }^{50}$ FSB, Policy Recommendations to Address Structural Vulnerabilities from Asset Management Activities (Jan 2017) at http://www.fsb.org/2017/01/policy-recommendations-to-address-structural-vulnerabilities-fromasset-management-activities/.
} 
that ${ }^{51}$ there may be a trade-off between preserving banking sector stability and promoting competitive banking markets. This is because bank stability is safeguarded if the level of profits for banks is high and not volatile. As competition in the banking sector can adversely affect incumbent banks' levels of profit and profit volatility, regulators need to consider carefully the unique balance of needs in their jurisdiction.

The above contextual survey shows that there are many complexities in the interrelationship between promoting competition in financial markets and other regulatory objectives. Regulators need to make strategic choices in each relevant context. Such strategic choices should underpin the governance of financial innovation, which as we discuss below, is not an unequivocal good. As the modern regulatory state is characterised by the adoption of technocratic regulatory agencies that are often economically-driven and provide governance to enable and not replace markets, ${ }^{52}$ an approach strongly endorsed by the FCA, ${ }^{53}$ we argue that regulators in the UK are well-placed to make such strategic choices within a rational framework that navigates the contextual complexities.

\section{Regulation and Innovation}

Many commentators agree that much of financial innovation produces efficiency and widening access to consumers. ${ }^{54}$ Financial innovation has led to improvements in efficiencies such as the reduction of agency and transaction costs. ${ }^{55} \mathrm{Kling}$ points out that cost-effective fixed rate mortgages for consumers would not be possible without the financial innovation of interest rate hedging derivative products..$^{56}$ Empirical research has found that cost-savings for financial institutions derived from financial innovation are often passed onto investors and borrowers. ${ }^{57}$ At a more macro level, Beck et al show that financial innovation correlates with increases in a country's growth opportunities and GDP per capita, ${ }^{58}$ and is important for emerging economies in their development..$^{59}$ Hence, innovation policy is often a key part of economic or industrial policy. ${ }^{60}$ To an extent, the FCA's Regulatory Sandbox and the PRA's New Bank Start-up Unit are facilitative frameworks supporting such broader economic policies.

\footnotetext{
${ }^{51}$ Christos Staikouras and Geoffrey Wood, 'Competition and Banking Stability in the Euro Area: The Cases for Greece and Spain' (2000) at http://papers.ssrn.com/paper.taf?abstract_id=233911.

52 David Levi-Faur, 'The Global Diffusion of Regulatory Capitalism' (2005) 598 ANNALS of the Academy of Political Science 12; Julie Froud and Anthony Ogus, 'Rational Social Regulation and Compliance Cost Assessment' (1996) 74 Public Administration 221; Anthony Ogus, Regulation: Legal Form and Economic Theory (Oxford; OUP 1994).

${ }^{53}$ FCA, Economics for Effective Regulation (March 2016).

${ }^{54}$ Chris Brummer,' Disruptive Technology and Securities Regulation' (2015) 84 Fordham Law Review 977.

${ }^{55}$ Ronald J Gilson, 'Locating Innovation: The Endogeneity of Technology, Organizational Structure and Financial Contracting' (2009) at http://ssrn.com/abstract=1492762.

${ }^{56}$ Andrew Kling, 'Not What They Had In Mind: A History of Policies that Produced the Financial Crisis of 2008' (2009) at http://ssrn.com/abstract=1474430.

${ }^{57}$ Lars Norden, Consuelo Silva Buston and Wolf Wagner, 'Financial Innovation and Bank Behavior: Evidence from Credit Markets' (2011) at http://ssrn.com/abstract=1800162.

58 Thorsten Beck, Tao Chen, Chen Lin and Frank M. Song, 'Financial Innovation: The Bright and the Dark Sides' (2014) at http://ssrn.com/abstract=1991216. However there is also contrary research that shows such benefits to be limited for countries that already have stringent and developed bank regulations in place such as capital adequacy.

${ }^{59}$ Saumitra Jha, 'Sharing the Future: Financial Innovation and Innovators in Solving the Political Economy Challenges of Development' (2012) at http://ssrn.com/abstract=2001039 on how financial innovation penetrates the political economy and brings about stability for economic development.

${ }^{60}$ Maarten J Arentsen, Wouter van Rossum and Albert E Steenge (eds), Governance of Innovation

(Cheltenham: Edward Elgar, 2010).
} 
Regulation is seldom understood to be the paradigm that promotes innovation. There is the perspective that regulation may be a hindrance or disincentive to innovation. Often, regulation adopts certain technologies and therefore hinder the adoption of new or more efficient technologies. ${ }^{61}$ For example, a number of regulatory standards that apply to investment advice assume that human judgment and discretion is involved, ${ }^{62}$ and may therefore not easily be transposed into a context where investment decisions are programmed to be auto-executed (the decentralised autonomous organisation for example), ${ }^{63}$ or where investment recommendations are the result of smart algorithmic analysis (robo-advice for example). ${ }^{64}$ Regulation based on 'old' technology may strait-jacket the manner in which financial services are to be provided, and may in time become under-inclusive or unsuitable. ${ }^{65}$ Innovations may also skirt the regulatory perimeter and raise questions of whether regulatory objectives are under-provisioned. ${ }^{66}$

The latter is particularly important as much of financial innovation are not unequivocal goods. Financial innovation has yielded a mixture of benefits and harms. In terms of benefits, improved efficiencies and access to finance have been achieved, but increased levels of social and economic risk have also entailed. ${ }^{67} \mathrm{~A}$ survey of the literature on what drives financial innovation highlights the dark side of such developments. Regulatory and tax environments ${ }^{68}$ are often important, and knowledge revolutions in economic, legal, communications and digital technologies ${ }^{69}$ are utilised towards financial innovation that is aimed at regulatory arbitrage (Knoll, 2008), ${ }^{70}$ i.e. exploiting gaps in regulation or regulatory regimes so that cost in compliance can be mitigated while pursuing profitable financial intermediation activity. For example, the development of processes to liquefy long-term relationship-based assets such as mortgage loans into liquid, standardised marketable securities has been motivated by the desire to evade stringent capital adequacy rules imposed on banks. ${ }^{71}$

\footnotetext{
${ }^{61}$ Giuseppe Nicoletti and Stefano Scarpetta, 'Regulation, Productivity and Growth: OECD Evidence' (World Bank Research Paper 2003).

62 Such as the 'suitability' standard in the FCA Handbook COBS 9; the EU Markets in Financial Instruments Directive 2014, Art 25(2). It is arguable that the fiduciary standard applicable in the US is also premised upon human judgment, see Melanie Fein, 'FINRA's Report on Robo-Advisors: Fiduciary Implications' (2016) at http://ssrn.com/abstract=2768295.

${ }^{63}$ Carla Reyes, Nizan Packin and Benjamin P Edwards, 'Distributed Governance' (2016) at https://ssrn.com/abstract=2884978.

${ }^{64}$ Darren Tedesco, 'I, Robo-Adviser? Creating the Blended Adviser Experience' (2015) Journal of Financial Planning 17.

${ }^{65}$ Eric Biber, Srah E Light, JB Ruhl and James Salzman, ' Regulating Business Innovation as Policy Disruption: From the Model T to Airbnb' (2017) Vanderbilt Law Review forthcoming, at http://ssrn.com/abstract id=2951919.

${ }^{66}$ Missing out on the social benefits of innovation was pointed out in Timothy A Slating and Jay P Kesan, 'Making Regulatory Innovation Keep Pace with Technological Innovation' (2011) Wisconsin Law Review 1009.

${ }^{67}$ Eg see Josh Lerner and Peter Tufano, 'The Consequences of Financial Innovation: A Research Agenda' (2009) at https://www.aeaweb.org/conference/2010/retrieve. php?pdfid=351.

68 Ian M Ramsay, 'Financial Innovation and Regulation: The Case of Securitisation' (1993) 4 Journal of Banking and Finance Law and Practice 169.

${ }^{69}$ Above, W Scott Frame and Lawrence J White, 'Technological Change, Financial Innovation, and Diffusion in Banking' in Allen N. Berger, Philip Molyneux, and John O.S. Wilson (eds), The Oxford Handbook of Banking (2nd ed OUP 2015).

${ }^{70}$ Michael S Knoll, 'The Ancient Roots of Modern Financial Innovation: The Early History of Regulatory Arbitrage' (2008) 87 Oregon Law Review 93.

${ }^{71}$ Ian M Ramsay, 'Financial Innovation and Regulation: The Case of Securitisation' (1993) 4 Journal of Banking and Finance Law and Practice 169.
} 
Regulatory arbitrage, if left unattended to by regulators, could in time increase systemic risks. ${ }^{72}$ This is because relatively un or under-regulated markets tend to create volumes of credit that may not be stringently under-written or generally well-controlled. Increased levels of debt across households and corporations could raise the risks of systemic fragility in the financial system. ${ }^{73}$ Further, the level of conduct risks posed to consumers or investors could be high as consumers increasingly depend on financial markets to meet their staple saving needs, and become a captive market that can be exploited..$^{74}$

In particular, Awrey ${ }^{75}$ proposes a supply-side theory of financial innovation that posits that financial innovation is driven by intermediaries' need to create monopolies over their products in the short term in order to extract maximum rents in an extremely competitive environment. Thus, one can be sceptical of the social utility and welfare-enhancing benefits to the investing society. For example, Kay discusses a complex retail product called the 'kick-out' bond where investors buy into an Indexlinked product over a fixed term, and are able to 'get out' at intervals where upsides have been achieved or otherwise remain invested until maturity. ${ }^{76}$ The complex structure of the product leaves many investors less than able to appraise real investment and liquidity risks, and Kay queries what social utility is achieved by such innovation.

Short-termist profit-seeking behaviour, although rationalised by the economic theory of the firm, could drive financial intermediary firms to produce financial innovation that is questionable in terms of social benefit, and could also adversely affect social welfare. For example, the financial innovation of derivatives, which was developed to hedge future financial risks is now a major subject of speculative trading in order to generate short-term profits for financial intermediaries. ${ }^{77}$ Much of financial innovation is poised to exploit investors' value misperceptions in order to make short-term gains for financial intermediaries, ${ }^{78}$ and mis-sold to investors. ${ }^{79} \mathrm{~A}$ number of empirical researchers have also found that the development of highly leveraged products, such as synthetic exchange-

\footnotetext{
72 Tim Adam and Andre Guettler, 'Pitfalls and Perils of Financial Innovation: The Use of CDS by Corporate Bond Funds' (2015) 55 Journal of Banking and Finance 204; Margaret M Blair, 'Financial Innovation and the Distribution of Wealth and Income' (2010) at http://ssrn.com/abstract=1656451; Tanju Yorulmazer, 'Has Financial Innovation Made the World Riskier? CDS, Regulatory Arbitrage and Systemic Risk' (Federal Reserve Bank of NY Paper, 2013) at http://ssrn.com/abstract=2176493.

${ }^{73}$ FSB, 'FinTech Credit: Market Structure, Business Models and Financial Stability Implications' (May 2017) at http://www.fsb.org/wp-content/uploads/CGFS-FSB-Report-on-FinTech-Credit.pdf.

${ }^{74}$ A phenomenon termed as financialisation, see Ismail Erturk, Julie Froud, Sukhdev Johal, Adam Leaver and Karel Williams, 'The Democratization of Finance? Promises, Outcomes and Conditions' (2007) 14 Review of International Political Economy 553.

75 Dan Awrey, 'Towards a Supply-Side Theory of Financial Innovation' (2013) 41 Journal of Comparative Economics 401; Dan Awrey, 'Complexity, Innovation, and the Regulation of Modern Financial Markets' (2012) 2 Harvard Business Law Review 235.

76 John Kay, 'Bonds designed to leave savers bemused', Financial Times (16 Nov 2010) at https://www.ft.com/content/1912d062-f1ba-11df-bb5a-00144feab49a.

77 Emilios Avgouleas, 'Regulating Financial Innovation: A Multifaceted Challenge to Financial Stability, Consumer Protection, and Growth' in Moloney, Ferran and Payne (eds), Oxford Handbook of Financial Regulation (Oxford University Press, 2015); Lars Norden, Consuelo Silva Buston and Wolf Wagner, 'Financial Innovation and Bank Behavior: Evidence from Credit Markets' (2011) at http://ssrn.com/abstract=1800162.

${ }^{78}$ Brian J Henderson and Neil D Pearson, 'The Dark Side of Financial Innovation' (2009) at http://ssrn.com/abstract=1342654.

79 Nicola Gennaioli, Andrei Schleifer and Robert Vishny, 'Financial Innovation and Financial Fragility' (2010) at http://ssrn.com/abstract=1688940.
} 
traded funds serve primarily speculative purposes instead of genuinely beneficial economic purposes. $^{80}$

Financial innovation seems to be a double-edged sword, and in Awrey's words, 'welfareindeterminate' ${ }^{81}$ However, the observed response on the part of many regulators is the prolonged adoption of a wait-and-see attitude that ultimately fails to catch up with the materialisation of problems. ${ }^{82}$ Regulators have tended to be cautious of stifling innovation, but have perhaps also been restrained due to an expertise gap between them and the industry. Arguably, they are schooled too heavily in favouring leaving markets to work. ${ }^{83} \mathrm{It}$ is mistaken to assume that that the private incentives that drive financial innovation are socially aligned, or that restrained regulatory approaches to new phenomena are necessarily proportionate in nature. Regulators run the risk of creating shortfalls in meeting their regulatory objectives, or worse, facilitating the creation of externalities, such as in the global financial crisis 2007-9.

Vermeulen et al ${ }^{84}$ support a pro-active role for regulators in relation to financial innovation. Regulators need to assess whether socially costly regulatory barriers should be adjusted and also whether innovative activities need to be governed in order not to compromise public interest objectives. However, the pro-active approach towards regulation and innovation comes with a few hazards. This approach risks having a preponderant pro-innovation bias and can fall short of providing governance for financial innovation..$^{85}$ The FCA's and PRA's pro-active approaches include being involved in bringing to market financial innovations. Although this approach allows regulators to gain deeper insights and understanding into products and market structures, such involvement raises the hazard of regulatory capture and the perception of 'regulatory warranty'.

Moreover, early regulation before an innovation has become mature may quickly be avoided or become obsolete. This is because regulators cannot foresee comprehensively all the risks that need to be managed or indeed may make incorrect judgments about where risks lie. MacNeil ${ }^{86}$ proposes an alternative approach to regulating innovation where market discipline and private litigation may be more robustly fostered to bring problems to light. The private law-creation process is arguably ideal for delicate balances to be struck in the articulation of legal rights and obligations, such a process ultimately feeding into the debate as to whether public regulation and standards are necessary. However regulation may be needed to facilitate such private accountability to begin with, so that contractual exclusions do not stifle the opportunities to develop private law jurisprudence. There is also a role for regulators to consider what may be efficiently standardised in due course.

\footnotetext{
${ }^{80}$ Margaret M Blair, 'Financial Innovation and the Distribution of Wealth and Income' (2010) at http://ssrn.com/abstract=1656451; Wenxi Jiang and Hongjun Yan, 'Financial Innovation, Investor Behavior, and Arbitrage: Evidence from the ETF Market' (2016) at http://ssrn.com/abstract=2023142.

${ }^{81}$ Dan Awrey, 'Complexity, Innovation, and the Regulation of Modern Financial Markets' (2012) 2 Harvard Business Law Review 235.

82 Nathan Cortez, 'Regulating Disruptive Innovation' (2014) 29 Berkeley Technology Law Journal 175.

83 Timothy A Slating and Jay P Kesan, 'Making Regulatory Innovation Keep Pace with Technological Innovation' (2011) Wisconsin Law Review 1009.

${ }^{84}$ Erik Vermeulen, Mark Fenwick and Wulf A Kaal, 'Regulation Tomorrow: What Happens when Technology is Faster than the Law?' (2016) at http://ssrn.com/abstract=2834531.

${ }^{85}$ State policy for innovation is usually characterised by being facilitative, supportive and even pro-active in terms of energising and funding activity, see Bo Caarlson, 'Entrepreneurship and Public Policy in Merging Clusters' in Annika Rickne et al (eds), Innovation Governance in an Open Economy (Oxford: Routledge 2012) at 251, but regulators have mandates to govern and control behaviour and activity within the scope of their jurisdiction and should not arguably pursue a single-minded promotion approach.

${ }^{86}$ Iain MacNeil, 'Innovation, Law and Regulation' (2017, on file with author).
} 
Regulators' proactivity towards financial innovation is arguably sound but this should not be a simplistic pursuit of promoting innovation, in light of the complexities in the interrelationship between regulation and innovation. Indeed regulators should develop regulatory strategy based on understanding these complexities in order to ensure that care is taken in this new regulatory approach. Such a framework for regulatory strategy should, as we propose, be constructed in a manner that facilitates rational, well-reasoned and consistent decision-making, supported by mechanisms of accountability.

\section{Innovation and Competition}

Finally, in our overview of the complex context for regulatory strategy, we observe that the PRA and FCA pursue the promotion of innovation as a proxy strategy for promoting competition. This is arguably an unconventional regulatory strategy. The traditional arsenal in a regulator's toolkit for promoting competition is regulation and intervention against anti-competitive practices. ${ }^{87}$ Anticompetitive regulation generally relates to ex post remedies such as penalising cartels and abusive behaviour in market dominance. The regulatory toolkit is commonly understood to be targeted at correcting market behaviour, not at intervening in markets themselves by introducing or promoting challenger products and firms.

Although one must not understate the FCA's sustained efforts in market investigations of anticompetitive practices in the financial markets, including in wholesale corporate finance, ${ }^{88}$ asset management, ${ }^{89}$ and retail financial products such as mortgages ${ }^{90}$ etc, the deliberate promotion of challenger outfits that use alternative and new forms of technology is a new and unconventional measure. It is arguable that such a measure is itself somewhat distortive of markets as challenger services and products benefit from regulators' promotion (albeit for a limited time under the Sandbox or Mobilisation approach).

Promoting innovation is not conceptually the same as promoting competition (which is the FCA's mandated regulatory objective in legislation). Innovation is driven by legal frameworks that protect innovators' rights, therefore incentivising innovation as an entrepreneurial activity. Protective laws in intellectual property such as patents and copyright are proprietary in nature and tend to confer exclusive exploitation rights (or in other words, a form of monopoly) upon the intellectual property rights holders. Innovation is arguably promoted within a conceptual paradigm that is potentially antithetical to that of competition, as competition laws and principles seek to reduce monopolistic practices in order to improve market competition. Further, promoting innovation is situated within a paradigm that is focused on the individual or firm, while promoting competition is situated within a

\footnotetext{
${ }^{87}$ Competition Act 1998 and subsequent amendments form the basis of the UK's competition law. This area of policy is however largely shaped by EU legislation transposed in the UK. For an overview of powers and enforcement against anti-competitive practices such as price fixing, cartels, abuse of dominant positions, see Richard Whish and David Bailey, Competition Law (Oxford: OUP 2012).

${ }^{88}$ FCA, Investment and Corporate Banking Market Study (Oct 2016) at https://www.fca.org.uk/publication/market-studies/ms15-1-3-final-report.pdf; and the FCA's proposed reforms to remove anti-competitive practices such as contractual restrictions in FCA, Reforming the Availability of Information in the UK Equity IPO Process (March 2017) at https://www.fca.org.uk/publications/consultationpapers/reforming-availability-information-uk-equity-ipo-process.

${ }^{89}$ FCA, Asset Management Market Study (Interim Report Nov 2016); Final Report (2017) at https://www.fca.org.uk/publication/market-studies/ms15-2-3.pdf.

${ }^{90}$ As part of the 'Responsible Lending Review', the competitiveness of the residential mortgage sector will be reviewed in this ongoing endeavour: FCA, Feedback Statement: Call for Inputs on Competition in the Mortgage Sector (May 2016) at https://www.fca.org.uk/publication/feedback/fs16-03.pdf which indicates that the FCA will undertake a market study in this area to determine next steps.
} 
paradigm focused on the market. In adopting the proxy strategy of promoting innovation to promote competition, the FCA and PRA risk conflating firm perspectives with market-based ones, and may develop excessive sympathies with firm-based perspectives.

There is a need for the FCA and PRA to keep under review their assumption that promoting financial innovation is aligned with promoting competitive markets. To an extent the selection criteria for the Regulatory Sandbox engages with this, as the FCA does not admit of applicants producing innovation that may only be derivative or may not generate consumer utility. Nevertheless it is important for the regulators to map their firm-based perspectives onto market-based perspectives, so that the competitive potential of firms is coherently and consistently assessed. We argue that this should form part of regulatory strategy and will be addressed in our proposal for a rational model for strategic choices to be made.

\section{A Rational Model for Regulatory Strategy}

In governing financial innovation, regulators need to engage with balancing and potentially trading off different regulatory objectives and priorities. The FCA is in particular mandated to pursue several regulatory objectives, and commentators have warned that multiple objectives for a regulator necessarily entail strategic choices of trade-offs. ${ }^{91}$ The FCA's predecessor the Financial Services Authority, a single regulator with multiple objectives, arguably made erroneous strategic choices in stewarding multiple regulatory objectives leading up to the global financial crisis 2007-9. ${ }^{92}$ Hence the UK regulators should do well to heed the lessons of the FSA and ensure that strategic choices can be optimally made.

A key aspect of a framework for regulatory strategy is to ensure that balance and trade-offs can be made in a well-reasoned and consistent manner. We propose that the introduction of a significant dose of rationality in the implementation of the Sandbox and Mobilisation initiative is essential for regulatory strategy. This not only secures consistency and credibility in regulatory policy for governing financial innovation but also mitigates the intense relational influences that come through in the interfaces of regulator-firm engagement. This is consistent with the FCA's purported approach in pursuing economically effective regulation..$^{93}$

First, we propose that there should be a systematic and rational approach to measuring the costs and benefits of innovation and/or competition, as well as regulation, by using the Sandbox and Mobilisation environments. Regulatory strategy should be informed by such findings.

The Sandbox and Mobilisation environments suspend regulation for delimited amounts of time during testing of a firm's innovation or challenger capacity. This testing environment should not only be put towards testing of the market viability of products and services, but should also serve as testing environments for the costs and benefits of regulation, innovation and competition. The testing environments create an environment sans regulation that can allow the social benefits and harms of the firm's innovations, products and services to be measured. Indeed, regulators can also calibrate the testing environments to suspend different types of regulation at different stages in order to measure the levels of social benefits and harms generated by firm activities, and changes in

\footnotetext{
${ }^{91}$ E Wymeersch, "The Structure of Financial Supervision in Europe: About Single, Twin Peaks and Multiple Financial Supervisors" at http://papers.ssrn.com/sol3/papers.cfm?abstract id=946695.

92 FSA, 'The Turner Review: A Regulatory Response to the Global Banking Crisis' (March 2009)

http://www.fsa.gov.uk/pubs/other/turner review.pdf; Eilis Ferran, "The Break-up of the Financial Services Authority" (2011) Oxford Journal of Legal Studies 455.

${ }^{93}$ FCA, Economics for Effective Regulation (March 2016).
} 
such levels between stages. These results can provide an informed picture as to what social benefits may be hindered by the cost of regulation, and what social harms are indeed prevented or addressed. Both the benefits and cost of financial activity and regulation can be drawn out in the testing environments. Such results can be analysed at firm level and at an aggregate level in order to inform regulatory decisions and policy-making.

The methodology of such cost-benefit analyses can be derived from regulatory cost-benefit analyses already performed for the introduction of new regulation in the UK. Cost-benefit analyses have been introduced in the UK where new regulation is introduced in order to rationalise policy-making in the UK. ${ }^{94}$ This is similar to initiatives elsewhere such as regulatory impact assessments in the US and EU. This form of analysis provides a rational information context to determine if new regulatory measures can be justified. Sunstein ${ }^{95}$ is careful however to advocate that the quantitative results of cost-benefit analyses should not per se determine regulatory policy, but play an important role in governing regulators' discretion and in ensuring that regulatory policy is a result of rational and wellinformed deliberations.

Cost-benefit analyses have however been criticised to be poorly carried out and failing to serve their purpose largely because (a) regulatory agencies fail to and in many instances are not able to quantify certain social benefits; ${ }^{96}$ and (b) regulatory agencies ignore the cost-benefit matrix and proceed with their chosen regulatory policy regardless. ${ }^{97}$

However, we propose that the Sandbox and Mobilisation environments are rather optimal for carrying out meaningful cost-benefit analyses as such analyses would be based on data and information obtained during the testing period and before regulatory decisions are made. Such earlier stage cost-benefit analyses are regarded by commentators to be particularly useful in the formative stage of regulatory policy or decisions..$^{98}$ Hence, they may suffer less from the problem of being merely cosmetic after regulators have already decided on their policy preferences.

The chiefly quantitative paradigm for cost-benefit analyses may nevertheless not capture social benefits that are hard to quantify, or qualitative characteristics. Wiener argues that qualitative analyses should feature to form a holistic picture for the information context. ${ }^{99}$ Further, in order to achieve meaningful comparison between quantifiable cost and social benefits that are indirect or hard to quantify, it is possible to employ reasonable estimates ${ }^{100}$ or bridging analytical mechanisms (such as Sunstein's 'breakeven analysis' that urges regulators to consider how small social benefits

\footnotetext{
94 Julie Froud and Anthony Ogus, 'Rational Social Regulation and Compliance Cost Assessment' (1996) 74 Public Administration 221.

${ }^{95}$ Cass R Sunstein, "The Cost-Benefit State" (Coase-Sandor Institute for Law \& Economics Working Paper No. 39, 1996); Cass R. Sunstein, 'The Limits of Quantification' (2014) 102 California Law Review 1369.

96 Jonathan S Masur and Eric A Posner, 'Unquantified Benefits and the Problem of Regulation Under Uncertainty' (2016) 102 Cornell Law Review 87; Cass R. Sunstein, 'The Limits of Quantification' (2014) 102 California Law Review 1369.

97 Jonathan S Masur and Eric A Posner, 'Unquantified Benefits and the Problem of Regulation Under Uncertainty' (2016) 102 Cornell Law Review 87; Mark Harrison, 'Assessing the Impact of Regulatory Impact Assessments' (2009) 16 Agenda 41 at http://ssrn.com/abstract=1906482.

${ }^{98}$ Christopher Carrigan and Stuart Shapiro, 'What's Wrong with the Back of the Envelope? A Call for Simple (And Timely) Benefit-Cost Analysis' (2016) Regulation and Governance 1.

99 Jonathan Wiener, 'Better Regulation in Europe' (2006) 59 Current Legal Problems 447.

${ }^{100}$ FCA, Economics for Effective Regulation (March 2016); Cass R. Sunstein \& R obert W. Hahn, "A New Executive Order for Improving Federal Regulation? Deeper and Wider Cost-Benefit Analysis" (John M. Olin Program in Law and Economics Working Paper No. 150, 2002); Cass R Sunstein, "The Cost-Benefit State" (Coase-Sandor Institute for Law \& Economics Working Paper No. 39, 1996).
} 
could be or how large regulatory cost could be before a regulatory measure yields zero benefits. This ensures that regulators employ proportionality in regulatory strategy even if costs and benefits cannot be precisely quantified). ${ }^{101}$ We are of the view that the Sandbox and Mobilisation initiative provide environments for documenting and measuring a suite of social benefits (and costs) as intense engagement between regulators and firms is implemented and extensive reporting is expected on the part of firms. The implementation of the Sandbox and Mobilisation should ensure that the relevant cost-benefit information can be collected and reported, and there should be some dedication of resources on the part of the regulators to analyse the returns within a quantitative and qualitative cost-benefit matrix. Such can be carried out at firm level and can be aggregated, for each Sandbox or Mobilisation cohort for example, to provide higher-level perspectives.

We suggest that cost-benefit analyses should be performed towards the end of the Sandbox or Mobilisation for each firm. This information context should form the basis for the Sandbox and Mobilisation unit's regulatory decision for each firm as well as development in thinking for regulatory policy reform if relevant.

Further, aggregate level analyses are important as they should be communicated to senior management for the purposes of developing higher-level principles or thinking on regulatory strategy. Such higher level governance reflects regulators' risk appetites and priorities, qualitative matters that shape and are shaped by the rational cost-benefit analytical exercises discussed above. As the FCA for example has indicated desire to embrace more technologically-led innovations even in the interfaces that deal with current regulatory compliance, i.e. regtech, ${ }^{102}$ more comprehensive and coherent thinking is needed at senior management level, in the form of regulatory strategy, to chart the regulators' course in navigating new technologically-led landscapes while maintaining objectivity and the fundamental stewardship of their regulatory objectives.

By re-orienting the Sandbox, Advice Unit and Mobilisation towards rationality, regulatory strategy can be better informed and strategic choices can be made in a manner that is credible and consistent for he purposes of governing financial innovation. Policy development and regulatory design can also be developed to be more proportionate- a form of precisioning in regulation that could countervail the criticism that regulation is often one size-fits-all. It is possible that more exact cost-benefit findings can assist regulators in determining at a strategic level whether to introduce regulatory regimes tailored and proportionate to certain innovative business models. Such precisioning in regulatory measures can be fashioned so that the cost of regulatory compliance, which reflects the price to pay for achieving public interest objectives (such as financial stability or consumer protection) can be calibrated proportionately to the level of social benefits obtained (such as financial inclusion or consumer benefits relating to choice and better market prices). Such a considered and proportionate approach seems to fall in line with the FCA's articulated framework for 'Economics for Effective Regulation'. ${ }^{103}$

The next Section turns to argue that the framework for regulatory strategy should be underpinned by appropriate organisational governance and accountability in order to protect its optimal qualities. These supporting pillars are essential for effectively and ultimately governing financial innovation.

\section{Organisational Governance and Accountability}

\footnotetext{
${ }^{101}$ Cass R. Sunstein, 'The Limits of Quantification' (2014) 102 California Law Review 1369.

102 FCA, Call for Input: Supporting the Development and Adoption of RegTech (Nov 2015) and Feedback

Statement: Call for Input: Supporting the Development and Adoption of RegTech (July 2016).

${ }^{103}$ FCA, Economics for Effective Regulation (March 2016).
} 
Regulators' close proximity to firms in the Sandbox, Advice or Mobilisation initiative may compromise regulators' objectivity in making regulatory decisions or framing new policy or reforms. Hence, it is important to subject the relational dimensions to a framework for governance and accountability. Such is aimed at preserving objectivity and rationality in regulatory decision-making and policy formulation.

Regulatory capture is a problem often highlighted in relation to financial regulators. They are susceptible to being influenced by firms during opportunities of engagement in consultation and feedback, and due to firms' sustained lobbying power. The 'revolving' door between the regulator and industry (where senior industry figures often take up high regulatory positions and regulatory staff become attracted to industry jobs) is also an important factor. ${ }^{104}$ Although regulators need not be dominated by the industry's agenda, subtle forms of influence that induce sympathy can often influence regulatory policy and decisions. Such sympathy can be a result of previous experience in the industry, trust in the industry for its expertise and sophistication (discussed as a feature of the industry's epistemic authority in influencing policy and law-making), ${ }^{105}$ as well as simply prolonged exposure to the industry's perspectives.

The Sandbox and Mobilisation route are environments where regulators and firms engage in perhaps greater intensity than under regular supervision, giving rise to many opportunities for regulatory sympathy. Although the innovation and business development on the part of firms would be rather complete by the time of entering into the Sandbox or Mobilisation, the regulators are nevertheless involved in firms' final developmental phases in achieving an interface with markets. This level of involvement risks being overly intimate with the 'business' aspects of the firm, and may affect regulators' judgment about the firm and in relation to wider regulatory strategy.

Regulators may also become impressed by the innovations and novelty they see, giving rise to a form of capture by the sophistication and authority of the industry. Regulatory sympathy may also arise from prolonged exposure to the industry's perspectives, hence influencing regulatory decisionmakers to be persuaded relatively easily of the merits and benefits of firms' services and products. Further, regulators may engage in gentle coaching exercises to assist firms in testing to emerge successfully.

The intensity of regulator-firm engagement should not as a consequence be diluted as a response to fear of capture, as the relational dimension is key to gaining information regarding industry developments for the purposes of determining the effectiveness of existing regulatory policy and whether changes are needed. The preferred way forward is putting in place a governance framework to mitigate the influences of capture upon regulatory decision-making and policy.

First, anchoring the Sandbox and Mobilisation environments in rational framework for regulatory strategy goes some way towards mitigating influences from capture. The rationality required in producing and reflecting upon the results of cost-benefit analyses for firms and at an aggregate level is an important facet for protecting regulatory objectivity.

Further, we suggest other internal governance mechanisms targeted at protecting regulatory objectivity. As discussed above, the framework for regulatory strategy should involve internal accountability to senior levels of management in a position to shape regulatory strategy. Further the

\footnotetext{
${ }^{104}$ Daniel C Hardy, 'Regulatory Capture in Banking' (IMF Working Paper 2006) at http://ssrn.com/abstract=892925.

105 Mads Andenas and Iris H-Y Chiu, The Foundations and Future of Financial Regulation (Oxford: Routledge 2014) at chapter 3 and citations therein.
} 
PRA and FCA could consider rotating regulatory decision-makers in the Sandbox and Mobilisation units so that fresh sets of eyes from the regulator would look at new cohorts of applicants for testing. Internal rotation could be useful for mitigating excessive regulatory sympathy and can generally be good organisational practice.

Next, Baxter ${ }^{106}$ proposes that in order to mitigate regulatory capture of financial regulators, the regulatory policy process should accommodate a wider range of stakeholders so that the dominant influence of the industry can be moderated. Hence, we also propose channels of external accountability in order to mitigate any subtle influences of capture that entails from intense engagement with firms in promoting innovation. This involves regulators reaching out to other constituents such as independent bodies, other stakeholders, think-tanks etc, in order to create an environment of greater and richer deliberations and discussions. This model of 'tripartism' (referring to regulators, industry and other constituents) can also be usefully adapted to ensure that regulatory decision and policy in relation to Sandbox and Mobilisation firms, as well as financial innovation and challenger firms in general, are made in as objective a manner as possible. At the moment the FCA and PRA are required to consult a number of stakeholder panels in relation to policy or regulatory reform. ${ }^{107}$ Perhaps the duty to consult the Consumer Panel can be widened to include regulatory decisions for Sandbox and Mobilisation firms, and the Consumer Panel can be jointly maintained by the PRA and FCA. Or the Consumer Panel could be asked to sample a number of the cost-benefit analyses supporting samples of regulatory decisions for Sandbox and Mobilisation firms in order to ensure that there is some external and independent input into regulatory decision-making in the Sandbox and Mobilisation unit.

We are also in favour of the establishment of a new Panel for the PRA and FCA jointly in order to deliberate on and act as a sounding board for broader policy matters relating to financial innovation and challenger firms. An Innovation Panel for example, which comprises of independent and qualified experts, can engage with regulators so as to provide non-industry based perspectives in relation to regulatory policy development for innovations and financial markets competition. They could also be co-opted to provide independent monitoring of the regulators' strategy framework in relation to governing financial innovation. The formalisation of a third-party Panel for the above helps in de-biasing regulators and provides a useful alternative information resource from the industry.

External accountability is important in scrutinising the performance of the regulators themselves in experimental forays and regulatory innovations. Hence we believe that a framework for regulatory strategy to govern financial innovation should also include accountability mechanisms not only within the regulators themselves but also externally. ${ }^{108}$ Further, if regulatory reform is to be developed, it is important for such reform not be perceived as excessively influenced by the

\footnotetext{
${ }^{106}$ Lawrence G Baxter, 'Capture in Financial Regulation: Can We Channel It Toward the Common Good?' (2011) 21 Cornell Journal of Law and Public Policy 3.

107 Sections $1 \mathrm{M}$ to $1 \mathrm{Q}, 2 \mathrm{~L}$ to $2 \mathrm{~N}$ Financial Services and Markets Act 2000 amended by the Financial Services Act 2012, applying to the FCA and PRA respectively. The PRA needs to consult a Practitioner Panel, and the FCA maintains a Practitioner Panel, Small Business Practitioner Panel, Market Participants Panel and Consumer Panel.

${ }^{108}$ Christian Voegtlin and Andreas Georg Scherer, 'Responsible Innovation and the Innovation of Responsibility: Governing Sustainable Development in a Globalized World' (2015) at http://ssrn.com/abstract=2716152 on the necessity of governing innovation in order to ensure that social responsibility objectives are also met alongside the private interests of exploiting and profiting from innovation.
} 
industry. External channels of accountability can work to constrain regulators from making choices based on ill-explained preferences ${ }^{109}$ and also protect them from pro-business political pressures. ${ }^{110}$

\section{Conclusion}

Financial innovation is dynamic and constantly arising. In this changing landscape, the UK regulators are determined to engage with the fast-paced developments in the industry as 'fintech', 'techfin' and 'regtech' could quickly elude the regulators' grasp without some form of pro-active initiative. The FCA's Regulatory Sandbox and Advice initiative, as well as the PRA's Mobilisation initiative for challenger banks are novel regulatory mechanisms introduced to bring technologically-led financial innovation out of their shadows and designed to help the regulators meet the 'promoting competition' regulatory objective. Although these new mechanisms are only starting to capture a wider scope of financial innovation for the development of regulatory policy, they are poised to extend in scope and grow in importance. In this light this article considers the potential of the Sandbox, Advice and Mobilisation regimes for further development to become more mature and comprehensive regimes for governing financial innovation.

We argue that the Sandbox, Advice and Mobilisation regimes should provide governance for and not be excessively focused on promoting market innovations. We raise some early concerns with the current approaches and propose to re-orient the current approaches towards a regulatory strategy framework for governing financial innovation. The interrelationships between regulatory objectives, promoting competition and encouraging innovation are complex and could involve synergies as well as tensions. Hence, a regulatory strategy framework is necessary to rationally evaluate the costs and benefits of market innovations and regulatory regimes. In this way, regulators have a more optimal and informed context in which to navigate their regulatory priorities. We believe this to be consistent with the FCA's and PRA's economically-driven models for regulation. Further, we urge the regulators to review their assumption that promoting innovation is aligned with promoting competition, as the tensions between the two should not be glossed over. Finally, we suggest that appropriate governance and accountability mechanisms are needed for the regulatory strategy framework.

\footnotetext{
109 Jonathan Wiener, 'Better Regulation in Europe' (2006) 59 Current Legal Problems 447; Mark Harrison, 'Assessing the Impact of Regulatory Impact Assessments' (2009) 16 Agenda 41 at http://ssrn.com/abstract=1906482.

${ }^{110}$ Cass R Sunstein, "The Cost-Benefit State" (Coase-Sandor Institute for Law \& Economics Working Paper No. 39, 1996); Cass R Sunstein, 'Cost-Benefit Analysis and the Separation of Powers' (1981) 23 Arizona Law Review 1267.
} 